\title{
Bradykinin increases resensitization of purinergic receptor signaling in glioma cells
}

Héctor E López-Valdés ${ }^{*}$, Luis Beltran-Parrazal ${ }^{2}$, Kevin C Brennan, Andrew C Charles ${ }^{1}$

\begin{abstract}
Background: Purinergic receptor-mediated signaling plays an important role in the function of glial cells, including glial tumor cells. Bradykinin is also an important paracrine mediator which is highly expressed in brain tumors and may correlate with their pathological grade. Interaction between bradykinin and purinergic signaling may therefore be involved in the regulation of glial tumor cells.

Results: We examined the effect of bradykinin on glial purinergic signaling in an immortalized glioma cell line. Confocal calcium imaging revealed that ATP evokes an increase in $\left[\mathrm{Ca}^{2+}\right]_{i}$ in the U87 human astrocytoma cell line. This response was reduced with repetitive application of ATP, likely due to receptor desensitization. However exposure to bradykinin increased the $\mathrm{Ca}^{2+}$ response to a second application of ATP, consistent with increased resensitization. The bradykinin effect on resensitization was similar in the absence of extracellular $\mathrm{Ca}^{2+}$ or in the presence of the PKC activator PMA, but was inhibited by the protein phosphatase inhibitor okadaic acid and the PI3K inhibitor LY294002.
\end{abstract}

Conclusions: Modulation of protein phosphatases and the PI3K pathway may represent a mechanism by which bradykinin potentiates purinergic signaling in glial cells.

\section{Background}

ATP is a primary extracellular signaling molecule for glial cells in the CNS [1,2]. In astrocytes, ATP is a key messenger for the intercellular communication of calcium waves, in which increases in $\left[\mathrm{Ca}^{2+}\right]_{\mathrm{i}}$ propagate from cell to cell across multiple cells [3-5]. Glial cell calcium waves have been characterized extensively in vitro in a variety of different tissue preparations, and also more recently in vivo in rodent cortex and retina [6-10]. They are thought to play physiological roles in the modulation of neuronal activity and vascular function, in addition to contributing to pathological processes such as cortical spreading depression and seizures [11,12]. Purinergic signaling is also believed to play an important role in the development and proliferation of glial cells under both physiological and pathological conditions, including those associated with glial tumors [13-15].

Glial cells respond to ATP through P2 purinergic receptors that belong to two families: P2Y G protein-

\footnotetext{
* Correspondence: hlopezv@ucla.edu

'Department of Neurology, David Geffen School of Medicine, University of California, Los Angeles, CA, USA

Full list of author information is available at the end of the article
}

coupled receptors (GPCR) and P2X ligand gated ion channels. Activation of $\mathrm{P} 2 \mathrm{Y}$ purinergic receptors triggers G-protein mediated activation of phospholipase $\mathrm{C} \gamma$ $\left(\mathrm{PLC}_{\gamma}\right)$ and increases levels of inositol 1,4,5-triphosphate $\left(\mathrm{IP}_{3}\right)$ and diacylglycerol (DAG), leading to elevations in intracellular calcium concentration and the activation of protein kinase C (PKC). By contrast, activation of P2X purinergic receptors leads to an increase in intracellular calcium concentration by influx of extracellular calcium through the receptor channel. In glial cells, the sustained increase in $\left[\mathrm{Ca}^{2+}\right]_{\mathrm{i}}$ evoked by ATP is mediated predominantly via activation of P2Y purinergic receptors, although the response to higher concentrations of ATP may also involve $\mathrm{Ca}^{2+}$ influx through P2X receptors [1].

Activation of GPCRs by agonists not only results in the G protein- dependent activation of the effector system, but also triggers coordinated molecular mechanisms governing the ongoing response of the receptors to further stimulation [16,17]. GPCR receptors show attenuation or loss of responses by repetitive agonist exposure, referred to as desensitization. Reduction of GPCR responsiveness to an agonist over time represents
Ciomed Central

(c) 2010 López-Valdés et al; licensee BioMed Central Ltd. This is an Open Access article distributed under the terms of the Creative Commons Attribution License (http://creativecommons.org/licenses/by/2.0), which permits unrestricted use, distribution, and reproduction in any medium, provided the original work is properly cited. 
an important physiological feedback mechanism that protects against both acute and chronic receptor overstimulation. After a period of desensitization, receptors recover their responses to agonists (resensitization), which enables receptors to maintain their ability to respond to agonists over time [17].

GPCR desensitization involves multiple distinct events including the uncoupling of receptors from their $\mathrm{G}$ proteins, the internalization and sequestration of receptors to endosomes, and down-regulation [16]. Receptor G protein uncoupling in response to receptor phosphorylation is the most rapid means of attenuating GPCR responsiveness and occurs within seconds to minutes following agonist activation. Phosphorylation is mediated by two families of protein kinases: the second messenger dependent protein kinases (e.g. PKA, PKC) and the G protein-coupled receptor kinases GRPKs; [18]. Receptor sequestration is also initiated within seconds to minutes of receptor activation and potentially contributes to receptor desensitization by limiting the number of plasma membrane accessible receptor binding sites. Down-regulation, a decrease in the total cellular complement of GPCRs, occurs in response to longer-term exposure to agonist from minutes to hours [18]. Resensitization of receptors involves the reversal of these processes, namely receptor dephosphorylation by phospatases, recovery of sequestered receptors to the plasma membrane, and increased synthesis and or trafficking of receptors to their sites of function [17].

Bradykinin is a nonapeptide (or kinin) formed from precursors (kininos) through actions of plasma and tissue kallikreins [19]. Kinins are implicated in physiological and pathological processes such as vasodilatation and inflammation [19]. Two kinin-specific GPCR have been reported, B1R and B2R. The B1R mediates the actions of Lys-des-Arg - bradykinin whereas B2R is activated by the main kinin, bradykinin $[19,20]$. Activation of B2R is preferentially coupled to G proteins of the $G \alpha-q$ subtypes, which in turn activate $\mathrm{PLC}_{\beta}$, leading to production of IP3 and release of intracellular calcium $[19,20]$. B2R activation also activates PKC, phosphatase A2, phospholipase $C$, and phosphoinositide 3-kinase (PI3K), and stimulates production of nitric oxide $[19,20]$. B2R's are expressed in many different cells including astrocytes [19-25] and human astrocytic tumors [26,27]. It has been reported that B2 receptors are more highly expressed in glioma cells as compared with normal astrocytes [28] and the level of expression of $\mathrm{B} 2$ receptors may be correlated with the grade of human gliomas [29].

Bradykinin and ATP-mediated signaling may interact via multiple pathways. Bradykinin potentiates the ATP response in Xenopus oocytes that express P2X receptors [30]. Meanwhile, ATP causes a desensitization of B2R in a neuroblastoma cell line [31] and bradykinin promotes/ induces ATP release from astrocytes [32]. In this work, we explore the effects of bradykinin on purinergic receptor signaling in the U87 human astrocytoma cell line. We show that bradykinin promotes resensitization of P2Y purinergic receptors via activation of PI3K and the phosphatase A2 pathways.

\section{Methods}

\section{Cell culture}

Human astrocytoma U87 cells were grown in DMEM/ F12 mixture (50-50) medium supplemented with 10\% $(\mathrm{V} / \mathrm{V})$ fetal calf serum, 100 units $/ \mathrm{ml}$ penicillin, and 10 $\mathrm{mg} / \mathrm{ml}$ streptomycin in humidified air with $5 \% \mathrm{CO}_{2}$ at $37^{\circ} \mathrm{C} .1 \times 10^{6}$ cells were grown to sub-confluent density on Poly-D-lysine treated round glass cover slips $(18 \mathrm{~mm}$ diameter) for 4-6 days prior to experimentation.

\section{Measurement of $\left[\mathrm{Ca}^{2+}\right]_{i}$}

Cells were loaded with $5 \mu \mathrm{M}$ fluo-4-AM for $20 \mathrm{~min}$ at room temperature in Hanks Buffered Saline Solution (HBSS) with HEPES (pH 7.38) that was used as the standard experimental solution. All experiments were performed with constant perfusion $(2 \mathrm{ml} / \mathrm{min})$ at room temperature $\left(22^{\circ} \mathrm{C}\right)$ on a Nikon Diaphot microscope coupled to a custom confocal imaging system as previously described [33]. Briefly, excitation from a $475 \mathrm{~nm}$ diode laser was delivered via scanning mirrors to the specimen through a $40 \times$ lens. Fluorescence emission was gathered through a dichroic mirror and 535 bandpass filter to a photomultiplier tube (Hamamatsu) and images were acquired at $1 \mathrm{~Hz}$ for 6 minutes by an image acquisition board (Bitflow Raven) controlled by Video Savant software. Before application of test substances, cells were continuously perfused for 10 minutes with standard solution. Ligands were added for the duration specified by continuous perfusion. For dose-response relationships of bradykinin, the compound was applied for 5 minutes.

\section{Bradykinin Pretreatment and Repetitive ATP application}

After exposure to either control solution or $200 \mathrm{nM}$ bradykinin for 5 minutes, cells were then washed for 10 minutes with HBSS-HEPES, after which ATP $(10 \mu \mathrm{M})$ was applied for 1 minute, ATP was washed off for 2 minutes, followed by a second 1-minute application of ATP. The PKC activator PMA $(1 \mu \mathrm{M})$, the BK2R antagonist HOE-140 $(1 \mu \mathrm{M})$, and the phosphatase and kinase inhibitors (Okadaic acid, $40 \mathrm{nM}$ and LY294002, $50 \mu \mathrm{M}$, respectively) were applied for 10 minutes prior to application of bradykinin. All chemicals were dissolved in HBSS-HEPES. For experiments with $\mathrm{Ca}^{2+}$ free medium, ATP was applied in HBSS-HEPES containing no added $\mathrm{Ca} 2+$, after which cells were returned to normal HBSS-HEPES. 


\section{Analysis}

Regions of interest $(30 \times 30$ pixels $)$ were placed in the center of the cell body of every single cell in each microscopic field, and fluo4 fluorescence vs. time was determined for each cell using ImageJ and Origin 6.0 software (Northampton, MA, USA). $\mathrm{Ca}^{2+}$ responses were characterized based on $\Delta \mathrm{F} / \mathrm{F}_{\mathrm{o}}$ calculated as $\left(\mathrm{F}_{1}\right.$ $\left.\mathrm{F}_{0}\right) / \mathrm{F}_{0}$, where $\mathrm{F}_{1}$ is the fluorescence at a given time and $\mathrm{F}_{0}$ is the basal mean fluorescence 1 minute before of application of test substances. Peak $\Delta / F_{o}$ was determined for each individual cell for each ATP application, and these peak responses were compared for individual cells to determine the extent of resensitization. The area under the curve (AUC) for each $\left[\mathrm{Ca}^{2+}\right]_{\mathrm{i}}$ response was also quantified using Origin software and values for AUC were also compared for the $1^{\text {st }}$ and $2^{\text {nd }}$ ATP response as an indication of resensitization. The ratio of the peak $\Delta / F_{o}$ or AUC for the $2^{\text {nd }}$ vs. $1^{\text {st }}$ response to ATP was designated as the $\%$ resensitization for each cell, and these values were averaged for all cells. A sigmoidal dose-response curve was fitted by Origin 6.0 (Northampton, MA, USA). Statistical analysis was performed using GraphPad Prizm 4.0 (La Jolla, CA, USA). Data are presented as mean \pm SEM; $p<0.05$ was considered significant.

\section{Results}

\section{Bradykinin $\left[\mathrm{Ca}^{2+}\right]_{\mathrm{i}}$ response}

Since activation of B2R leads to release of intracellular calcium $[19,20]$, we first determined the concentration that evoked the maximum $\left[\mathrm{Ca}^{2+}\right]_{\mathrm{i}}$ response in $\mathrm{U}-87$ cells. Results from those experiments (Figures 1A-B) showed that maximum averaged peak response reached a plateau at $200 \mathrm{nM}$ of bradykinin, we therefore used this concentration to investigate the effects of bradykinin on the response to ATP. $\left[\mathrm{Ca}^{2+}\right]_{\mathrm{i}}$ was monitored for 10 minutes following bradykinin exposure. After the initial response to bradykinin, no further changes in $\left[\mathrm{Ca}^{2+}\right]_{\mathrm{i}}$ were observed over the next 10 minutes.

\section{Desensitization and Resensitization of ATP receptors}

GPCR, including P2Y purinergic receptors, undergo desensitization and resensitization after agonist exposure [18]. We investigated whether bradykinin can affect these processes. When U-87 glioma cells were exposed to repetitive 1 minute application of ATP $(10 \mu \mathrm{M})$ separated by two minutes, the response for the second application of ATP showed a reduced $\left[\mathrm{Ca}^{2+}\right]_{\mathrm{i}}$ response (Figure 1C). Cells incubated with bradykinin (200 nM for 5 minutes) and then exposed to the same double application of ATP, ten minutes later, also showed a reduced $\left[\mathrm{Ca}^{2+}\right]_{\mathrm{i}}$ response. However, the peak and the AUC for second response to ATP were significantly ( $\mathrm{p}$ 0.001) larger than in control cells (Figure 1D), suggesting that previous exposure to bradykinin significantly increased the resensitization of P2Y receptors.

To confirm that the activation of $\mathrm{BK} 2 \mathrm{R}$ is necessary for the increase in the resensitization of the ATP receptors, we applied the selective $\mathrm{BK} 2 \mathrm{R}$ antagonist, $\mathrm{HOE}$ $140(1 \mu \mathrm{M})$ concurrently with bradykinin application. Cells treated with HOE-140 plus bradykinin showed no differences in the responses to ATP with respect to the control cells (standard solution); moreover, the evoked increase in the resensitization of the second response to ATP observed in the group with bradykinin alone was significantly blocked ( $\mathrm{p}<0.001$, Figures $2 \mathrm{~A}-\mathrm{B})$

Application of ATP $(10 \mu \mathrm{M})$ consistently evoked an increase in $\left[\mathrm{Ca}^{2+}\right]_{\mathrm{i}}$ in U87 cells. This response was blocked by pretreatment with the PLC inhibitor U73122 $(10 \mu \mathrm{M})$ and was not inhibited by the removal of extracellular $\mathrm{Ca}^{2+}$, indicating that the response was mediated primarily by G-protein coupled purinergic (P2Y) receptors as has been previously described [1].

To examine the contribution of extracellular calcium to the ATP resensitization, similar experiments were performed in $\mathrm{Ca}^{2+}$ free medium. When ATP was applied in $0 \mathrm{Ca}^{2+}$ medium, the amplitude of the first ATP response was not significantly different from those observed in normal $\mathrm{Ca}^{2+}$ medium (figures $3 \mathrm{~A}-\mathrm{B}$ ), suggesting that the response was due to release of $\mathrm{Ca}^{2}$ from intracellular stores. The increase in resensitization we observed with bradykinin application was also preserved in $0 \mathrm{Ca}^{2+}$ medium, although a significantly smaller peak amplitude (39\% average resensitization in $0 \mathrm{Ca}^{2+}$ vs. $55 \%$ average resensitization in normal $\mathrm{Ca}^{2+}$ medium, Figure $2 \mathrm{~A}, \mathrm{p}<0.001)$. These results indicate that $\mathrm{Ca}^{2+}$ influx is important for the resensitization of the response to ATP, likely in part by replenishing intracellular $\mathrm{Ca}^{2+}$ stores. However, $\mathrm{Ca}^{2+}$ influx through P2X receptors or other $\mathrm{Ca}^{2+}$ influx pathways is not required for the increased resensitization of the ATP response that is mediated by bradykinin.

To investigate the role of phosphorylation in the resensitization of GPCR/P2Y in response to bradykinin, we applied the PKC activator phorbol 12-myristate 13acetate (PMA, $1 \mu \mathrm{M}$ ) for 10 minutes prior to the application of bradykinin (15 minutes before the first ATP application). Treatment with PMA significantly ( $p<0.001)$ reduced the peak amplitude of the first ATP response in both bradykinin treated and untreated cells by about $40 \%$, with no significant difference between groups (Figures 3A). PMA treatment also significantly $(\mathrm{p}<0.001)$ reduced resensitization of the ATP response in both groups. However, the bradykinin treated cells still showed significantly $(\mathrm{p}<0.05)$ greater resensitization as compared with untreated cells (Figures 2A-B). These results indicate that activation of PKC significantly inhibits ATP mediated $\mathrm{Ca}^{2+}$ signaling and reduces 


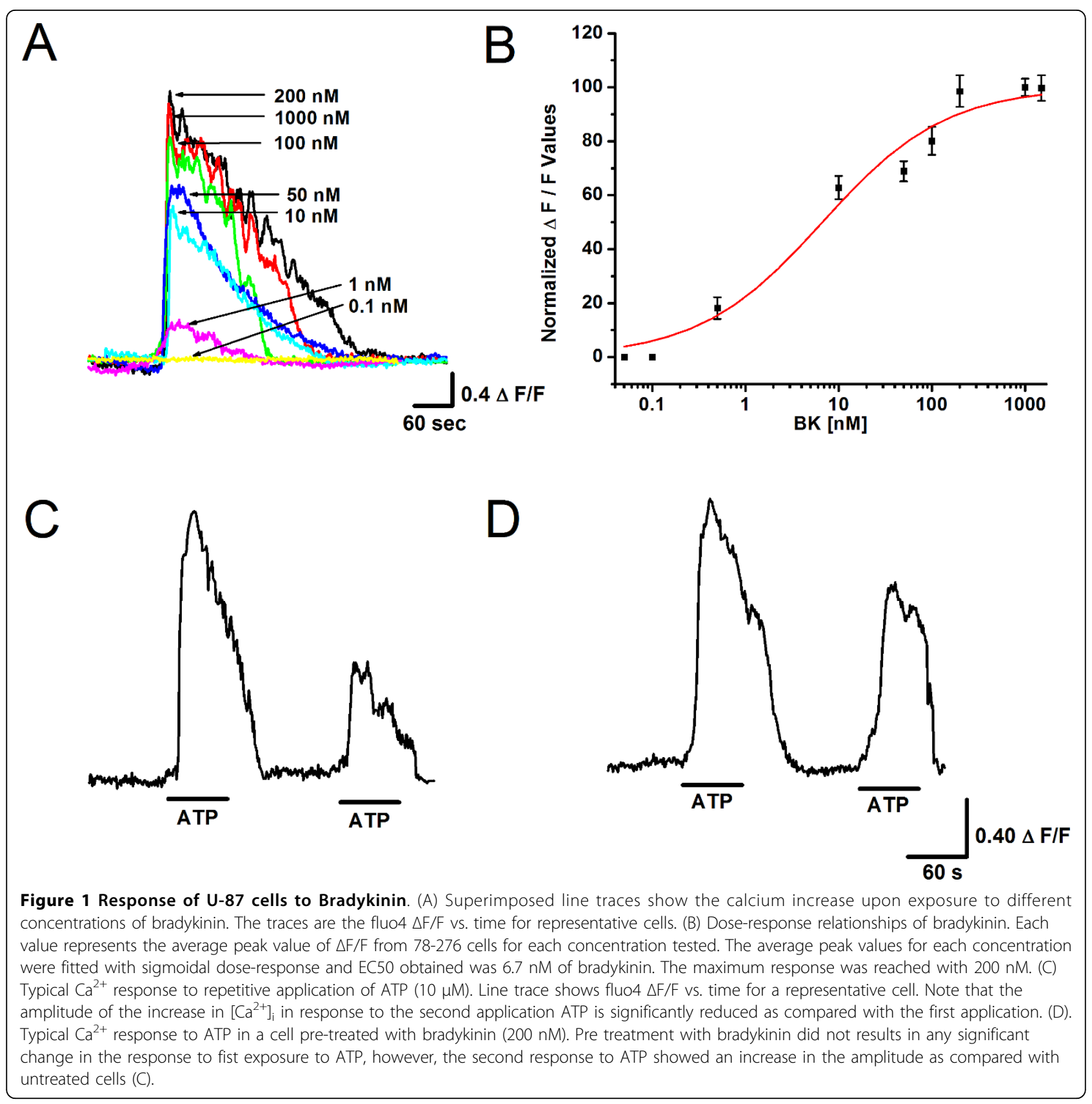

resensitization of the response to ATP. However, the effect of bradykinin on the resensitization of the ATP response continues to occur following activation of $\mathrm{PKC}$ by PMA.

The role of phosphatases in the GPCR/P2Y response was tested with okadaic acid (40 nM), a protein phosphatase 1 and 2A inhibitor. Okadaic acid did not have a significant effect on the initial response to ATP in bradykinin-treated and control cells (Figures 3A-B). However, okadaic acid blocked the bradykinin -evoked increase in resensitization of the second response to ATP (Figures 2A-B).

To determine the potential involvement of the PI3K pathway in the resensitization response to bradykinin, we applied the PI3K inhibitor LY294002 (50 $\mu \mathrm{M})$ to both control and bradykinin -treated cells. LY294002 significantly $(\mathrm{p}<0.001)$ inhibited both the initial response to ATP (Figures 3A-B) as well as the resensitization of the response to the second application of ATP. Treatment with LY294002 also inhibited the effect of 

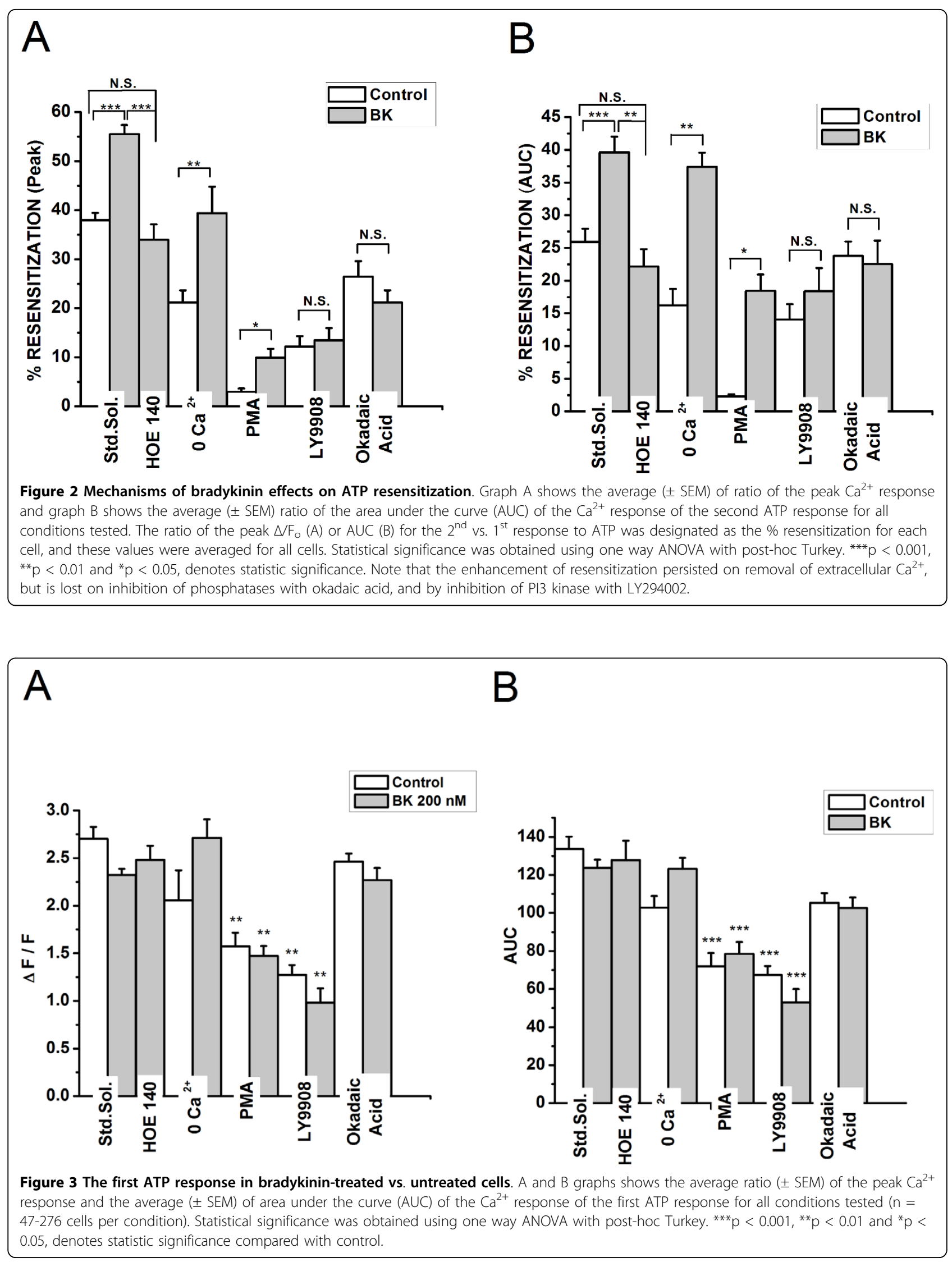
bradykinin on resensitization of the ATP response. (Figures 2A-B)

\section{Discussion}

Purinergic receptor-mediated signaling is critically important for the function of many cell types $[1,2]$, but relatively little is known about the process by which purinergic signaling interacts with other types of receptor-mediated signaling. Given the potential importance for this kind of interaction, especially in glial tumors, we investigated the role of bradykinin signaling on purinergic signaling in the human glioma cell line.

In U87 astrocytoma cells, the preincubation with bradykinin had no significant effect on the peak amplitude and area under the curve (AUC) in the first response to ATP. However both peak amplitude and AUC of the response to second application of ATP were significantly increased by bradykinin. That this effect was blocked by the bradykinin the specific antagonist HOE 140, confirm that the resensitization phenomenon we observed is mediated by the activation of bradykinin receptors.

The calcium response of U87 cells to ATP is mediated primarily by P2Y purinergic receptors, as shown by the persistence of the response in zero $\mathrm{Ca}^{2+}$ solution, as well as the complete inhibition of the response in cells treated with the PLC inhibitor U73122. The persistence of the bradykinin -induced increase in resensitization of the $\mathrm{Ca}^{2+}$ response to ATP in the absence of extracellular $\mathrm{Ca}^{2+}$ indicates that the entry of calcium through P2X receptors or other $\mathrm{Ca}^{2+}$ influx pathways is not required for the effect of bradykinin on resensitization. Because bradykinin activates $\mathrm{PKC}$, we investigated the effects of the PKC activator phorbol ester on ATP mediated calcium signaling and its modulation by bradykinin. Similar to the reports of others [34], we found that treatment with phorbol ester significantly reduced the initial response to ATP, and increased desensitization of the response. However, the increased resensitization of the ATP response in bradykinin treated cells was maintained, suggesting that PKC did not play a primary role in the bradykinin effect.

The resensitization effect of bradykinin was abolished by the phosphatase 1 and 2A inhibitor okadaic acid, consistent with a key role for dephosphorylation of P2Y purinergic receptors in the increased resensitization induced by bradykinin. Other investigators [34-36] have also found that phophatases are important for the resensitization of P2Y purinergic receptors, and their blockage with okadaic acid decreases receptor resensitization [36].

Our additional finding that the bradykinin effect was prevented by inhibition of PI3K with LY294002 is consistent with previous reports of a role for PI3K in resensitization of P2Y purinergic receptors in guinea pig Muller cells [37]. PI3K has been found to mediate phosphorylation and translocation of phospholipase Cgamma and resultant IP3 production in response to activation of $\mathrm{P} 2 \mathrm{Y}$ purinergic receptors - this could be one mechanism by which PI3 kinase inhibitors inhibit both the initial response to ATP and the resensitization of P2Y purinergic receptors [38].

Resensitization of GPCR's may occur both through recoupling of receptors to $\mathrm{G}$ proteins, as well as agonistdependent endocytosis of the receptor to endosomal compartment followed by dephosphorylation and recycling back to the membrane as a functional receptor [18]. The U87 cells mainly express P2Y1 purinergic receptors [39] and it has recently been reported that agonist-mediated endocytosis of P2Y1 purinergic receptors occurs over a period of 30 minutes, with recycling of endocytosed receptors occurring over a period of approximately 60 minutes [40]. The duration of this process is therefore significantly greater than the $1 \mathrm{~min}$ ute time period over which we observed increased resensitization of the ATP response in bradykinin treated cells. Thus, the effect of bradykinin that we observed is more likely to be due to a re-coupling of the receptor to $\mathrm{G}$ protein prior to recycling through the endosomal compartment.

The effects of bradykinin on ATP-mediated signaling could play multiple functional roles in the nervous system. B2 receptors are highly expressed on glioma cells, and the expression of these receptors may be correlated with tumor grade [29], suggesting that they may play a role in the abnormal growth and migration of these cells [28]. P2Ypurinergic receptors have also been implicated in the growth and migration of glial tumors [41-43]. Thus, potentiation of purinergic receptor signaling by bradykinin could play a role in CNS tumor formation and progression.

B2 receptors have also been a focus of investigation and potential therapies because of their role in opening the blood-tumor-barrier [44]. P2Y purinergic receptors are also highly expressed at the glio-vascular interface, suggesting that an interaction between bradykinin and P2Y purinergic receptors could play a role in the interaction of glioma cells with the vasculature [45]. Bradykinin is also well known as an important inflammatory mediator, with potential roles in the response of the brain to head injury, encephalitis, and ischemia [46]. Significant quantities of ATP may be released in association with these same events, which therefore represent other settings in which interaction between bradykinin and ATP-mediated signaling may be important [47]. Finally, both B2 and P2Y purinergic receptors may be involved in pain transmission. Bradykinin released in the setting of tissue damage or inflammation could therefore influence nociception by increased resensitization of P2Y purinergic receptors $[48,49]$. 


\section{Conclusions}

Our results indicate that bradykinin-evoked signaling has a significant influence on purinergic receptor signaling via the PI3 kinase pathway. Potentiation of purinergic signaling by increasing receptor resensitization may represent an important mechanism by which bradykinin modulates glial cell function.

\section{Abbreviations}

$\left[\mathrm{Ca}^{2+}\right]_{\mathrm{i}}$ : intracellular calcium concentration; ATP: adenosine $5^{\prime}$ triphosphate; PKC: protein kinase C; PMA: phorbol12-myristate 13-acetate; PI3K. Phosphoinositide 3-kinase.

\section{Acknowledgements}

This work was supported by NIDA DA05010 and the Johnny Carson Foundation (AC) and Larry L. Hillblom (KCB and AC).

\section{Author details}

${ }^{1}$ Department of Neurology, David Geffen School of Medicine, University of California, Los Angeles, CA, USA. ²Program of Neurobiology, Universidad Veracruzana, Xalapa, Veracruz, México.

\section{Authors' contributions}

HELV and LBP carried out all experiments; KCB and AC contributed to the writing of the manuscript and participated in experimental designs. All authors read and approved the final manuscript.

\section{Competing interests}

The authors declare that they have no competing interests.

Received: 10 May 2010 Accepted: 27 September 2010

Published: 27 September 2010

\section{References}

1. James G, Butt AM: $P 2 Y$ and $P 2 X$ purinoceptor mediated $\mathrm{Ca} 2+$ signalling in glial cell pathology in the central nervous system. Eur J Pharmacol 2002, 447:247-260.

2. Burnstock G: Physiology and Pathology of Purinergic Neurotransmission Physiol Rev 2007, 87:659-797.

3. Charles AC, Merrill JE, Dirksen ER, Sanderson MJ: Intercellular signaling in glial cells: calcium waves and oscillations in response to mechanical stimulation and glutamate. Neuron 1991, 6:983-992.

4. Guthrie PB, Knappenberger J, Segal M, Bennett MV, Charles AC, Kater SB: ATP released from astrocytes mediates glial calcium waves. J Neurosci 1999, 19:520-528.

5. Stout CE, Constantin JL, Naus CC, Charles AC: Intercellular calcium signaling in astrocytes via ATP release through connexin hemichannels. J Biol Chem 2002, 277:10482-10488.

6. Basarsky TA, Duffy SN, Andrew RD, MacVicar BA: Imaging spreading depression and associated intracellular calcium waves in brain slices. J Neurosc 1998, 18:7189-7199.

7. Chuquet J, Hollender L, Nimchinsky EA: High-resolution in vivo imaging of the neurovascular unit during spreading depression. J Neurosci 2007, 27:4036-4044.

8. Fam SR, Gallagher CJ, Salter MW: P2Y(1) purinoceptor-mediated Ca(2+) signaling and $\mathrm{Ca}(2+)$ wave propagation in dorsal spinal cord astrocytes. J Neurosci 2000, 20:2800-2808.

9. Newman EA: Propagation of intercellular calcium waves in retinal astrocytes and Müller cells. J Neurosci 2001, 21:2215-2223.

10. Peters $\mathrm{O}$, Schipke $\mathrm{CG}$, Hashimoto $Y$, Kettenmann H: Different mechanisms promote astrocyte $\mathrm{Ca} 2+$ waves and spreading depression in the mouse neocortex. J Neurosci 2003, 23:9888-9896.

11. Charles A: Intercellular calcium waves in glia. Glia 1998, 24:39-49.

12. Fiacco TA, McCarthy KD: Astrocyte calcium elevations: properties, propagation, and effects on brain signaling. Glia 2006, 54:676-90.

13. Dale N: Dynamic ATP signaling and neural development. J Physiol 2008, 586:2429-2436.
14. Morrone FB, Oliveira DL, Gamermann P, Stella J, Wofchuk S, Wink MR, Meurer L, Edelweiss MI, Lenz G, Battastini AM: In vivo glioblastoma growth is reduced by apyrase activity in a rat glioma model. BMC Cancer 2006, 6:226.

15. White N, Burnstock G: P2 receptors and cancer. Trends Pharmacol Sci 2006, 27:211-217.

16. Drake MT, Shenoy SK, Lefkowitz RJ: Trafficking of G protein-coupled receptors. Circ Res 2006, 99:570-582.

17. Ferguson SS: Evolving concepts in G protein-coupled receptor endocytosis: the role in receptor desensitization and signaling. Pharmacol Rev 2001, 53:1-24.

18. Ferguson SS, Caron MG: G protein-coupled receptor adaptation mechanisms. Semin Cell Dev Biol 1998, 9:119-127.

19. Moreau ME, Garbacki N, Molinaro G, Brown NJ, Marceau F, Adam A: The kallikrein-kinin system: current and future pharmacological targets. J Pharmacol Sci 2005, 99:6-38.

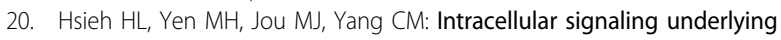
bradykinin-induced matrix metalloproteinase-9 expression in rat brain astrocyte-1. Cell Signal 2004, 16:1163-1176.

21. Leeb-Lundberg LM, Marceau F, Müller-Esterl W, Pettibone DJ, Zuraw BL: International union of pharmacology. XLV. Classification of the kinin receptor family: from molecular mechanisms to pathophysiological consequences. Pharmacol Rev 2005, 57:27-77.

22. Cholewinski AJ, Stevens G, McDermott AM, Wilkin GP: Identification of B2 bradykinin binding sites on cultured cortical astrocytes. J Neurochem 1991, 57:1456-1458.

23. Burch RM, Axelrod J: Dissociation of bradykinin-induced prostaglandin formation from phosphatidylinositol turnover in Swiss 3T3 fibroblasts: evidence for $G$ protein regulation of phospholipase A2. Proc Natl Acad Sci USA 1987, 84:6374-6378

24. Stephens GJ, Cholewinski AJ, Wilkin GP, Djamgoz MB: Calcium-mobilizing and electrophysiological effects of bradykinin on cortical astrocyte subtypes in culture. Glia 1993, 9:269-279.

25. Yanaga $F$, Hirata $M$, Koga $T$ : Evidence for coupling of bradykinin receptors to a guanine-nucleotide binding protein to stimulate arachidonate liberation in the osteoblast-like cell line, MC3T3-E1. Biochim Biophys Acta 1991, 1094:139-146.

26. Raidoo DM, Sawant S, Mahabeer R, Bhoola KD: Kinin receptors are expressed in human astrocytic tumor cells. Immunopharmacology 1999, 43:255-263.

27. Graness A, Adomeit A, Heinze R, Wetzker R, Liebmann C: A novel mitogenic signaling pathway of bradykinin in the human colon carcinoma cell line SW-480 involves sequential activation of a Gq/11 protein, phosphatidylinositol 3-kinase beta, and protein kinase $C$ epsilon. J Biol Chem 1998, 273:32016-32022.

28. Wang YB, Peng C, Liu YH: Low dose of bradykinin selectively increases intracellular calcium in glioma cells. J Neurol Sci 2007, 258:44-51.

29. Zhao Y, Xue Y, Liu Y, Fu W, Jiang N, An P, Wang P, Yang Z, Wang Y: Study of correlation between expression of bradykinin B2 receptor and pathological grade in human gliomas. Br J Neurosurg 2005, 19:322-326.

30. Paukert M, Hidayat S, Grunder S: The P2X(7) receptor from Xenopus laevis: formation of a large pore in Xenopus oocytes. FEBS Lett 2002, 513:253-258.

31. Czubayko U, Reiser $G$ : Desensitization of $P 2 U$ receptor in neuronal cell line. Different control by the agonists ATP and UTP, as demonstrated by single-cell Ca2+ responses. Biochem J 1996, 320:215-219.

32. Verderio C, Matteoli M: ATP mediates calcium signaling between astrocytes and microglial cells: modulation by IFN-gamma. J Immunol 2001, 166:6383-6391.

33. Beltran-Parrazal L, López-Valdés HE, Brennan KC, Díaz-Muñoz M, de Vellis J, Charles AC: Mitochondrial transport in processes of cortical neurons is independent of intracellular calcium. Am J Physiol Cell Physiol 2006, 291: C1193-1197.

34. Otero M, Garrad RC, Velazquez B, Hernandez-Perez MG, Camden JM, Erb L, Clarke LL, Turner JT, Weisman GA, Gonzalez FA: Mechanisms of agonistdependent and -independent desensitization of a recombinant P2Y2 nucleotide receptor. Mol Cell Biochem 2000, 205:115-123.

35. Santiago-Perez LI, Flores RV, Santos-Berrios C, Chorna NE, Krugh B, Garrad RC, Erb L, Weisman GA, Gonzalez FA: P2Y(2) nucleotide receptor signaling in human monocytic cells: activation, desensitization and 
coupling to mitogen-activated protein kinases. J Cell Physiol 2001, 187:196-208.

36. Flores RV, Hernández-Pérez MG, Aquino E, Garrad RC, Weisman GA, Gonzalez FA: Agonist-induced phosphorylation and desensitization of the P2Y2 nucleotide receptor. Mol Cell Biochem 2005, 280:35-45.

37. Weick M, Wiedemann $P$, Reichenbach $A$, Bringmann A: Resensitization of $\mathrm{P} 2 \mathrm{Y}$ receptors by growth factor-mediated activation of the phosphatidylinositol-3 kinase in retinal glial cells. Invest Ophthalmol Vis Sci 2005, 46:1525-1532.

38. Bony C, Roche S, Shuichi U, Sasaki T, Crackower MA, Penninger J, Mano H, Puceat M: A specific role of phosphatidylinoitol 3-kinase gamma. A regulation of autonomic $\mathrm{Ca}(2)+$ oscillations in cardiac cells. J Cell Biol 2001, 152:717-728.

39. Maier R, Glatz A, Mosbacher J, Bilbe G: Cloning of P2Y6 cDNAs and Identification of a Pseudogene: Comparison of Receptor Subtype Expression in Bone and Brain Tissues. Biochem Biophys Res Commun 1997, 237:297-302.

40. Tulapurkar ME, Zundorf G, Reiser G: Internalization and desensitization of a green fluorescent protein-tagged P2Y nucleotide receptor are differently controlled by inhibition of calmodulin-dependent protein kinase II. J Neurochem 2006, 96:624-634.

41. Morrone FB, Jacques-Silva MC, Horn AP, Bernardi A, Schwartsmann G, Rodnight $\mathrm{R}$, Lenz $\mathrm{G}$ : Extracellular nucleotides and nucleosides induce proliferation and increase nucleoside transport in human glioma cell lines. J Neurooncol 2003, 64:211-218.

42. Neary JT: Trophic actions of extracellular ATP: gene expression profiling by DNA array analysis. J Auton Nerv Syst 2000, 81:200-204.

43. Neary JT, Kang Y, Bu Y, Yu E, Akong K, Peters CM: Mitogenic signaling by ATP/P2Y purinergic receptors in astrocytes: involvement of a calciumindependent protein kinase $C$, extracellular signal-regulated protein kinase pathway distinct from the phosphatidylinositol-specific phospholipase C/calcium pathway. J Neurosci 1999, 19:4211-4220.

44. Borlongan CV, Emerich DF: Facilitation of drug entry into the CNS via transient permeation of blood brain barrier: laboratory and preliminary clinical evidence from bradykinin receptor agonist, Cereport. Brain Res Bull 2003, 60:297-306.

45. Simard M, Arcuino G, Takano T, Liu QS, Nedergaard M: Signaling at the gliovascular interface. J Neurosci 2003, 23:9254-9262.

46. Raidoo DM, Bhoola KD: Pathophysiology of the kallikrein-kinin system in mammalian nervous tissue. Pharmacol Ther 2006, 79:105-127.

47. Franke $H$, Krugel $U$, Illes P: P2 receptors and neuronal injury. Pflugers Arch 2006, 452:622-644.

48. Millan MJ: The induction of pain: an integrative review. Prog Neurobiol 1999, 57:1-164.

49. Abbracchio MP, Burnstock G, Boeynaems JM, Barnard EA, Boyer JL, Kennedy C, Knight GE, Fumagalli M, Gachet C, Jacobson KA, Weisman GA: International Union of Pharmacology LVIII: update on the P2Y G proteincoupled nucleotide receptors: from molecular mechanisms and pathophysiology to therapy. Pharmacol Rev 2006, 58:281-341.

doi:10.1186/1475-2867-10-35

Cite this article as: López-Valdés et al:: Bradykinin increases resensitization of purinergic receptor signaling in glioma cells. Cancer Cell International 2010 10:35.

\section{Submit your next manuscript to BioMed Central and take full advantage of:}

- Convenient online submission

- Thorough peer review

- No space constraints or color figure charges

- Immediate publication on acceptance

- Inclusion in PubMed, CAS, Scopus and Google Scholar

- Research which is freely available for redistribution

Submit your manuscript at www.biomedcentral.com/submit
Ciomed Central 